Original Research

\title{
Biohazards in International Road Transport Logistics in the Polish Part of the European Union's Eastern Border
}

\author{
Jacek Wasilewski ${ }^{1}$, Malgorzata Szczepanik ${ }^{2 *}$, Zbigniew Burski ${ }^{1}$ \\ ${ }^{1}$ Department of Power Engineering and Transportation, University of Life Sciences in Lublin, Lublin, Poland \\ ${ }^{2}$ Department of Applied Mathematics and Computer Science, University of Life Sciences in Lublin, Lublin, Poland
}

Received: 26 July 2017

Accepted: 10 September 2017

\begin{abstract}
Our paper presents the problem of real hazards for products (edible or inedible) and animals identified as a result of border control in international road transport. A border control system used on the Polish part of the eastern border of the European Union was selected and some data were analyzed concerning the number of checks and shipments rejected due to the epidemiological risk. The data have been collected from annual control reports for Poland. It has been shown that the biggest biological threat comes from the border with Belarus (most shipments were rejected). It was noted that the proportion of imported shipments rejected on the borders had a very strongly positive correlation (correlation coefficients: 0.96 and 0.99 ).
\end{abstract}

Keywords: biohazard, cross-border transport, food safety, agri-food products, animal transport

\section{Introduction}

Throughout history there have been cases of major epidemics in which the number of fatalities, e.g., from the plague, was four times higher than the total number of victims of the Second World War. Another epidemic (biological bomb) was called the Spanish Flu, in which the number of victims reached 20-50 million deaths worldwide [1-2].

In the context of biological hazards and the prevention of terrorist attacks, a series of works concerns the agriculture and food industry [3-7], as key economic sectors in all the countries of the world. Safety measures

*e-mail: malgorzata.szczepanik@up.lublin.pl are supported by the rapid alert system for food and feed (RASFF) set up by the European Commission in order to quickly inform member states of the risks concerning food products and the means of animal nutrition [8].

Sources of formation and consequences of food crises in the European Union have brought home the need for stringent requirements in the production and transportation of food [9-12]. In the current situation, the lack of mechanisms to track the product have caused the dioxin scare and the BSE crisis, which covered the entire food chain [13].

Even without the occurrence of bioterrorist activities, food contamination is a serious problem [14-15]. Every year in the United States it is the cause of more than 76 million illnesses, 325,000 hospitalizations, and 5,000 deaths. In Poland, the number of registered cases of poisoning and food infection of bacterial origin, for 


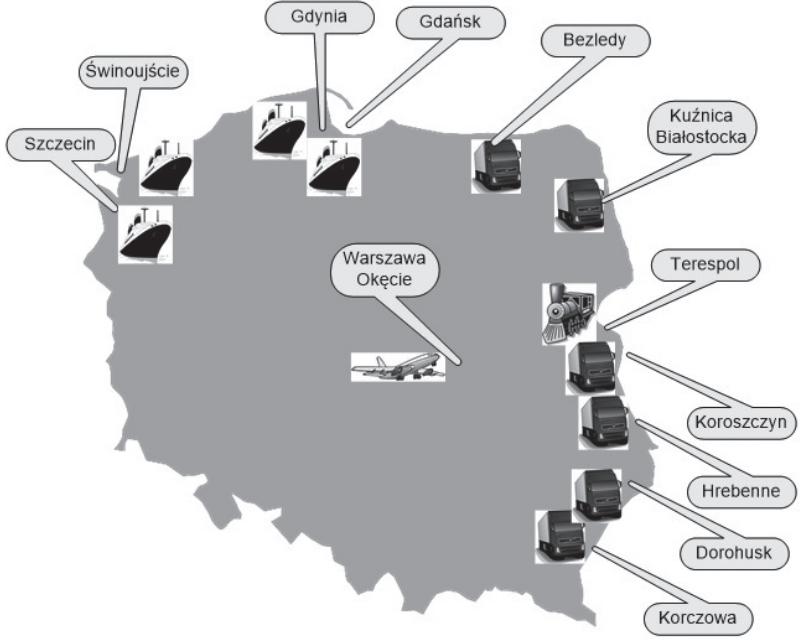

Fig. 1. Veterinary inspection posts at the Polish border. example, reached 30,515 in 1998 and 26,701 in 2000 [8].

The possibility of making intentional acts of terrorism using biological agents makes it very important to keep under control, e.g., production lines, laboratories, storage systems, and distribution companies in the agri-food industry, as well as the transport of products and animals (controls at border crossings, at places of departure and reception, etc.) [16-18].

The development of transport of food products and animals needs to ensure safety as well as protect the environment [19-25]. In addition, a number of other aspects of transport is regulated by the EU law, in terms of the competition between carriers, working conditions, technical standards of vehicles, and - of particular importance - the anticipation of terrorist threats and the reduction of potential losses [26-27].

Considering the threat of bioterrorism, one should take into account the implementation of transport communication systems in eastern Poland via Baltica

Table 1. List of veterinary inspection posts at the Polish border.

\begin{tabular}{|c|c|c|c|c|c|}
\hline $\begin{array}{l}\text { Name of border } \\
\text { crossing }\end{array}$ & $\begin{array}{l}\text { Neighbor- } \\
\text { ing country }\end{array}$ & $\begin{array}{l}\text { Type of } \\
\text { crossing }\end{array}$ & Voivodeship & $\begin{array}{c}\text { Category of } \\
\text { animals under control }\end{array}$ & Category of articles under control \\
\hline Bezledy (14) & Russia & road & Warmia-Masuria & $\mathrm{U}, \mathrm{E}, \mathrm{O}$ & $\begin{array}{l}\text { het, hent, nhet, nhent, all the means of } \\
\text { animal nutrition, and medicated feed }\end{array}$ \\
\hline Dorohusk & Ukraine & road & Lubelskie & $\mathrm{O}$ & het, nhet, (FR), nhent \\
\hline Gdańsk & Poland & seaport & Pomerania & & het, hent, nhet, nhent, (2) \\
\hline Gdynia & Poland & seaport & Pomerania & $\mathrm{U}, \mathrm{E}, \mathrm{O}$ & $\begin{array}{l}\text { het, hent, nhct, nhent, all the means of } \\
\text { animal nutrition, and medicated feed }\end{array}$ \\
\hline Korczowa & Ukraine & road & Subcarpatia & $\mathrm{U}, \mathrm{E}, \mathrm{O}$ & $\begin{array}{l}\text { het, hent, nhct, nhent, all the means of } \\
\text { animal nutrition, and medicated feed }\end{array}$ \\
\hline $\begin{array}{c}\text { Koroszczyn } \\
\text { (Kukuryki) }\end{array}$ & Belarus & road & Lubelskie & $\mathrm{U}, \mathrm{E}, \mathrm{O}$ & $\begin{array}{l}\text { het, hent, nhct, nhent, all the means of } \\
\text { animal nutrition, and medicated feed }\end{array}$ \\
\hline $\begin{array}{c}\text { Kuźnica } \\
\text { Białostocka (14) }\end{array}$ & Belarus & road & Podlaskie & $\mathrm{U}, \mathrm{E}, \mathrm{O}$ & $\begin{array}{l}\text { het, hent, nhct, nhent, all the means of } \\
\text { animal nutrition, and medicated feed }\end{array}$ \\
\hline Szczecin & Poland & seaport & West Pomerania & & $\begin{array}{l}\text { het, hent, nhct, nhent, all the means of } \\
\text { animal nutrition, and medicated feed }\end{array}$ \\
\hline Świnoujście & Poland & seaport & West Pomerania & & $\begin{array}{l}\text { het, hent, nhet, nhent, all the means of } \\
\text { animal nutrition, and medicated feed }\end{array}$ \\
\hline Terespol-Kobylany & Belarus & railway & Lubelskie & & $\begin{array}{l}\text { het, hent, nhct, nhent, all the means of } \\
\text { animal nutrition, and medicated feed }\end{array}$ \\
\hline Warszawa Okęcie & Poland & airport & Mazowiecki & $\mathrm{U}, \mathrm{E}, \mathrm{O}$ & $\begin{array}{l}\text { het, hent, nhct, nhent, (2), all the means of } \\
\text { animal nutrition, and medicated feed }\end{array}$ \\
\hline
\end{tabular}

Explanation of abbreviations

U: ungulates (cattle, sheep, goats, pigs, horses for slaughter)

E: registered horses

$\mathrm{O}$ : other animals

hct: products for human use (edible) stored at an appropriate temperature refrigerated/frozen

hent: products intended for human use stored at room temperature

nhct: inedible products (not intended for humans) held at an appropriate temperature chilled/frozen

nhent: inedible products (not intended for humans) kept at ambient temperature

(2): products of animal origin packaged

(14): products intended for carriage by the EU of animal origin intended for human consumption or imported from Russia under the specific procedures foreseen in relevant Community legislation

FR: products requiring storage at freezing temperature 
Table 2. The number of checks of products and imported animals shipments carried out in subsequent years at the eastern border.

\begin{tabular}{|c|c|c|c|c|c|c|c|c|}
\hline Name of border crossing & Neighboring country & 2008 & 2009 & 2010 & 2011 & 2012 & 2013 & 2014 \\
\hline $\begin{array}{c}\text { Dorohusk, Korczowa, } \\
\text { Hrebenne }\end{array}$ & Ukraine & 7,696 & 2,568 & 5,924 & 7,969 & 5,081 & 3,493 & 7,170 \\
\hline Bezledy & Russia (Kaliningrad district) & 257 & 191 & 188 & 151 & 108 & 89 & 58 \\
\hline $\begin{array}{c}\text { Koroszczyn-Terespol, } \\
\text { Kuźnica Białostocka }\end{array}$ & Belarus & 2,913 & 3,062 & 2,513 & 2,285 & 2,470 & 13,801 & 18,473 \\
\hline & Total & 10,866 & 5,821 & 8,625 & 10,405 & 7,659 & 17,383 & 25,701 \\
\hline
\end{tabular}

and via Carpatia in conjunction with the existing transEuropean transport network (TEN-T) and the system of national expressways and local roads [28-29]. An extension of those systems' connections to the transport network of other neighboring countries is expected in the near future.

Transport of food plays a very important role, since it largely affects consumer health. This particular mode of transport requires diligence and sanitary standards maintenance. There are no general restrictions on the movement of animal products in transit within the EU, since all EU countries have to apply common veterinary standards, although there is a need to determine the current security hazards in the case of products imported from outside the EU. This article analyzes the situation on the Polish part of the EU's eastern border.

\section{Results and Discussion}

\section{Analysis of the Legal Basis and Activities of the Polish Border Points of Food Control}

EU states have common veterinary, phytosanitary, and animal welfare standards that are in accordance with the Common Agricultural [30-31]. The Polish Act of 27 August 2003 "On Veterinary Border Control" [32] determines the rules for carrying out border checks of animals and products from third countries brought

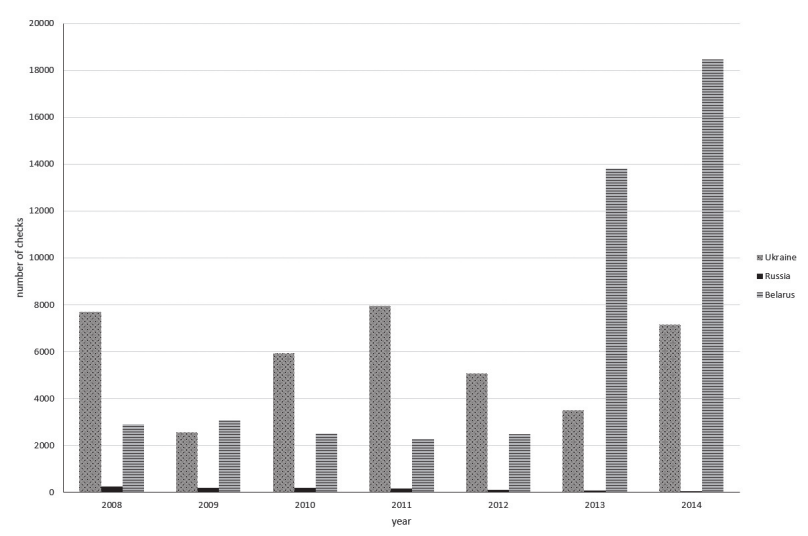

Fig. 2. Number of checks of products and imported animals shipments carried out in subsequent years into one of the EU states. In order to make controls, requirements have been set that must be met by the carrier, products transported, and border inspection posts. These posts should be located near the border crossing and in the area designated in accordance with customs legislation, and should be under the supervision of the border veterinarian who is responsible for the control.

The arrangement and list of particular veterinary border inspection posts [33] are shown in Fig. 1 and Table 1.

It can be observed that in Poland the vast majority of foodstuff transport checkpoints along the eastern border of the country (the EU) are road transport control posts. There is only one border post that controls rail transport (at Terespol-Kobylany).

Quality control of commercial agri-food products as well as of their storage and transport conditions consists in checking whether the articles meet the commercial quality requirements and if they are stored and transported in the proper way to preserve their

Table 3. Data on the number of veterinary border checks of shipments in 2011 within the import procedures.

\begin{tabular}{|c|c|c|c|}
\hline $\begin{array}{c}\text { Border } \\
\text { veterinary } \\
\text { inspection } \\
\text { post }\end{array}$ & $\begin{array}{c}\text { Number } \\
\text { of product } \\
\text { shipment } \\
\text { checks }\end{array}$ & $\begin{array}{c}\text { Number } \\
\text { of animal } \\
\text { shipment } \\
\text { checks }\end{array}$ & $\begin{array}{c}\text { Number } \\
\text { of rejected } \\
\text { shipments }\end{array}$ \\
\hline Bezledy & 122 & 122 & 0 \\
\hline Dorohusk & 1,446 & 0 & 0 \\
\hline Hrebenne & 5,399 & 0 & 27 \\
\hline Gdańsk & 1,217 & 0 & 16 \\
\hline Gdynia & 1,858 & 0 & 0 \\
\hline Korczowa & 875 & 249 & 3 \\
\hline $\begin{array}{c}\text { Koroszczyn/ } \\
\text { Terespol }\end{array}$ & 1,806 & 303 & 13 \\
\hline $\begin{array}{c}\text { Kuźnica } \\
\text { Białostocka }\end{array}$ & 176 & 0 & 0 \\
\hline $\begin{array}{c}\text { Warsaw } \\
\text { Okęcie }\end{array}$ & 235 & 206 & 3 \\
\hline Szczecin & 2,133 & 0 & 8 \\
\hline Świnoujście & 6 & 0 & 0 \\
\hline
\end{tabular}


Table 4. Data on the number of veterinary border checks of shipments in 2011 within the export procedures.

\begin{tabular}{|c|c|}
\hline $\begin{array}{c}\text { Border veterinary inspection } \\
\text { post }\end{array}$ & $\begin{array}{c}\text { Number of shipment } \\
\text { checks }\end{array}$ \\
\hline Bezledy & 801 \\
\hline Dorohusk & 0 \\
\hline Hrebenne & 3 \\
\hline Gdańsk & 32 \\
\hline Gdynia & 65 \\
\hline Korczowa & 993 \\
\hline Koroszczyn/Terespol & 3,765 \\
\hline Kuźnica Białostocka & 268 \\
\hline Warszawa Okęcie & 0 \\
\hline Szczecin & 0 \\
\hline Świnoujście & 0 \\
\hline
\end{tabular}

marketable quality.

In order to determine compliance with the provisions within the framework of these guidelines, the appropriate inspectors are authorized to check the documents and results of laboratory tests, thus enabling the identification of an article and control of its packaging and labeling, as well as storage and transport conditions.

In addition, the inspector may take samples for laboratory examination to determine the quality grade of a particular agri-food sector article. As a result of the inspection, a veterinary inspector or a person authorized to conduct the inspection may issue a ban on the article marketing, order the article submission to certain treatments, or order the destruction of the article at the expense of the holder. Furthermore, following quality control, the provincial inspector by decision may reclassify an article of agri-food industry to a lower class if this article does not meet the quality requirements for the commercial grade.

\section{Results of Border Control of Products and Animals in Statistical Terms}

The border controls were performed in accordance with European Commission guidelines. In particular, the border checks of animal welfare were conducted following Article 21, the Council Regulation [34], and comprised all animal shipments entering or leaving the European Union territory. The number of shipment controls of products and imported animals from 2008-2014 carried out on the eastern border obtained from annual control reports [35] is shown in Table 2 and Fig. 2.

On the border with Ukraine within the analyzed period, 5,700 inspections per year were conducted, on average. On the border with Belarus, the average number of inspections per year was the highest $(6,502)$, and the number of checks in the period 2008-2012 ranged between 2,285 and 3,062, while in 2013 and 2014 there was a significant increase in the number of inspections, respectively 13,801 and 18,473 .

The fewest checks were carried out on the border with Russia (an average of 148 per year), and their number decreased in subsequent years.

Exemplary data on the number of items checked (by product and animals), and rejected by border veterinarians in 2011 (under the procedures of import and export) [35] are presented in Tables 3 and 4.

In the case of border control in 2011, the border veterinary doctors conducted 5,199 checks of imported and exported shipments under the terms of animal welfare [35]. During the checks, deficiencies were found in 160 transports, representing $3.07 \%$ of all the controlled animal shipments. Most deficiencies were found in January (17 shipments: 6.27\%), March (17 shipments: $4.64 \%$ ), and November (25 packages: $4.19 \%$ ). They were found in the shipments of the following species of animals: pigs (104 shipments), cattle (51 shipments), and other (5 shipments).

The most common deficiencies related to exceeding the standards of travel time, improper filling of the journey log, lack of navigation system as recommended by [34], and lack of documents accompanying the transport of animals. The number of the shipments of imported products and animals rejected on the basis of inspections performed at the Polish eastern border [35] are shown in Table 5 and Figure 3.

Most shipments were rejected at the border with Belarus (on average 86 per year), then on the border with Ukraine (on average 36 per year), and the fewest on the border with Russia (on average 4 per year). Most shipments were rejected at the eastern border in 2010 (526) and on the border with Belarus in 2014 (230).

Shipments were most often rejected in 2010, and this

Table 5. Number of shipments of imported products and animals rejected in subsequent years .

\begin{tabular}{|c|c|c|c|c|c|c|c|c|}
\hline Name of border crossing & Neighboring country & 2008 & 2009 & 2010 & 2011 & 2012 & 2013 & 2014 \\
\hline Dorohusk, Korczowa, Hrebenne & Ukraine & 17 & 6 & 195 & 30 & 0 & 2 & 3 \\
\hline Bezledy & Russia (Kaliningrad district) & 1 & 0 & 30 & 0 & 0 & 1 & 2 \\
\hline $\begin{array}{c}\text { Koroszczyn-Terespol, Kuźnica } \\
\text { Białostocka }\end{array}$ & Belarus & 18 & 22 & 301 & 13 & 1 & 20 & 230 \\
\hline & Total & 36 & 28 & 526 & 43 & 1 & 23 & 235 \\
\hline
\end{tabular}




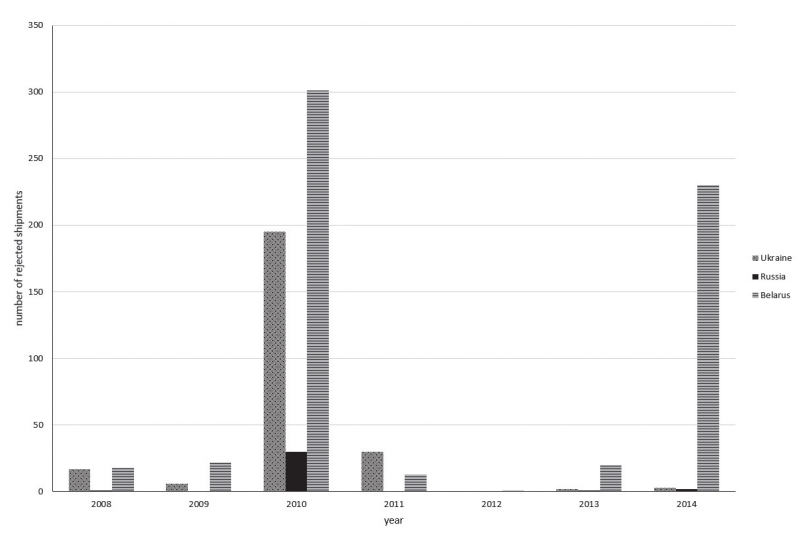

Fig. 3. Number of shipments of imported products and animals rejected in subsequent years.



Fig. 4. Proportion of shipments of imported products and animals rejected in subsequent years

applies to all the borders, with the highest percentage of rejected shipments (Fig. 4) on the border with Russia and on the border with Belarus.

An analysis was made of the interdependence of the number of shipments imported and rejected, and the proportion of shipments rejected at the Polish border in the studied years, calculating the correlation coefficients (Table 6).

It was noted that the proportion of imported shipments rejected at the borders was very strongly positively correlated (Table 6), while the numbers of rejected shipments were correlated strongly or very strongly. No significant correlations were found among the numbers of checks on the Polish border with Ukraine and Polish border with Russia, or on the Polish-Ukrainian and
Polish-Belarussian borders. The number of checks on the Polish border with Russia and the Polish border with Belarus were strongly negatively correlated (correlation coefficient: -0.74).

\section{Conclusions}

As is apparent from the above data, there is a risk of bioterrorism danger for countries across the world. Recommendations of security officials in Germany and other EU countries and international discussion topics are evidence of the possibility of local risks. Also, in the military field, in Poland, army training is conducted in the field of real biological, chemical, and radioactive munitions, the so-called live gentis. They are attended by international experts to combat this type of threat.

Moreover, inspections of means of transport should be performed with a general aim of reducing environmental pollution by fuel combustion products (in accordance with the current exhaust emissions standards). The effects of such pollution include respiratory system diseases, cardiovascular diseases, and cancer [36-39].

Based on the analysis of data obtained by government authorities, the following conclusions have been made:

1) Special monitoring was applied in cases of animal diseases, especially infectious ones, with regard to cattle, sheep, and goats (brucellosis, tuberculosis, encephalitis, leukemia, foot and mouth disease, etc.) and poultry (avian influenza, salmonellosis, Aujeszky's disease, and others).

2) The literature concerning this field points out that food manufacturers and transporters still have a big problem with microbiological contamination by bacteria from salmonella and listeria monocytogenes. The identified problems arise from the still not quite good sanitary condition of the equipment and the premise of the supervised entities that do not have or do not apply the appropriate hygienic procedures.

3) Research has shown that in quantitative terms the border control authorities have shown a high number of product and animal shipment checks, both imported (from 5,821 in 2009 to 25,701 in 2014) and exported (e.g., 5,927 in 2011).

4) On the basis of border shipment checks of products and animals imported into the European Union across the Polish eastern border, we found that the rejected shipments ranged extensively, e.g. in 2013 (23), 2014 (235), and in 2010 (526). Most shipments were rejected at the border with Belarus (on average

Table 6. Correlation coefficients on the basis of controls along the eastern border of Poland.

\begin{tabular}{|c|c|c|c|c|c|c|}
\hline \multirow{2}{*}{} & \multicolumn{2}{|c|}{ Number of controls } & \multicolumn{2}{c|}{ Number of rejected shipments } & \multicolumn{2}{c|}{ Percentage of rejected shipments } \\
\cline { 2 - 7 } & Poland-Russia & Poland-Belarus & Poland-Russia & Poland-Belarus & Poland-Russia & Poland-Belarus \\
\hline Poland-Ukraine & 0.14 & -0.03 & 0.98 & 0.73 & 0.96 & 0.99 \\
\hline Poland-Russia & & -0.74 & & 0.80 & & 0.99 \\
\hline
\end{tabular}


86 per year).

5) The analysis of the reports from subsequent years allows for the examination of correlations between the controls and their results on the borders of Poland and Belarus, Ukraine, or Russia. We found strong positive or very strong positive correlations of the numbers of rejected shipments on the particular borders (the strongest correlations were noted on the borders of Poland and Ukraine and of Poland and Russia (the correlation coefficient was 0.98).

6) Very strong correlations were observed among the proportions of imported shipments rejected in Poland at the borders with Belarus, Ukraine, and Russia (correlation coefficients above 0.95).

The obtained data and performed calculations show that significant biological hazards threaten the European Union at the eastern border with Belarus.

\section{References}

1. JOHNSON N.P.A.S., MUELLER J. Updating the accounts: global mortality of the 1918-1920 "Spanish" influenza pandemic. Bull Hist Med. 76, 105, 2002.

2. KOŚCIELNY R. Teoria spisku - czy grozi nam wojna biologiczna? (Conspiracy theory - does biological war threaten us?) Tygodnik Warszawski, Warszawa. 20, 2015.

3. BAERT K., VAN HUFFEL X., WILMART O., JACXSENS L., BERKVENS D., DIRICKS H., HUYGHEBAERT A., UYTTENDAELE M. Measuring the safety of the food chain in Belgium: Development of a barometer. Food Research International. 44 (4), 940, 2011.

4. ZACH L., DOYLE M.E., BIER V., CZUPRYNSK C. Systems and governance in food import safety: A U.S. perspective. Food Control. 27 (1), 153, 2012.

5. FERNÁNDEZ-SEGOVIA I., PÉREZ-LLÁCER A., PEIDRO B., FUENTES A. Implementation of a food safety management system according to ISO 22000 in the food supplement industry: A case study. Food Control. 43, 28, 2014.

6. CHEN K., WANG X., SONG H. Food safety regulatory systems in Europe and China: A study of how co-regulation can improve regulatory effectiveness. Journal of Integrative Agriculture. 14 (11), 2203, 2015.

7. RAITEN D.J., AIMONE A.M. The intersection of climate/environment, food, nutrition and health: crisis and opportunity. Current Opinion in Biotechnology. 44, 52, 2017.

8. SZCZAWIŃSKI J., ANUSZ K. Przeciwdziałanie bioterroryzmowi $\mathrm{w}$ rolnictwie i przemyśle spożywczym. (Counter-terrorism in agriculture and food industry.) Conf. VetMedica, Łódź, Poland, 20-21 maja. 1, 2005.

9. KNUDSEN I. The SAFE FOODS framework for integrated risk analysis of food: An approach designed for sciencebased, transparent, open and participatory management of food safety. Food Control. 21 (12), 1653, 2010.

10. LEBLANC D.I., VILLENEUVE S., BENI L.H., OTTEN A., FAZIL A., MCKELLAR R., DELAQUIS P. A national produce supply chain database for food safety risk analysis. Journal of Food Engineering. 147, 24, 2015.

11. BARLOW S.M., BOOBIS A.R., BRIDGES J., COCKBURN A., DEKANT W., HEPBURN P., HOUBEN G.F., KÖNIG J., NAUTA M.J., SCHUERMANS J., BÁNÁTI D. The role of hazard- and risk-based approaches in ensuringfood safety. Trends in Food Science \& Technology. 46 (2), Part A, 176, 2015.

12. TÄHKÄPÄÄ S., MAIJALA R., KORKEALA H., NEVAS M. Patterns of food frauds and adulterations reported in the EU rapid alert system for food and feed and in Finland. Food Control. 47, 175, 2015

13. KOHNEN A. Responding to the Threat of Agroterrorism: Specific Recommendations for the United States Department of Agriculture. BCSIA Discussion Paper 2000-29, ESDP Discussion Paper ESDP-2000-04, John F. Kennedy School of Government, Harvard University. 2000.

14. MILOŠKOVIĆ A., SIMIĆ V. Arsenic and Other Trace Elements in Five Edible Fish Species in Relation to Fish Size and Weight and Potential Health Risks for Human Consumption. Polish Journal of Environmental Studies. 24 (1), 199, 2015.

15. PUSZ W., MASCHER F., CZEMBOR E., CZEMBOR J., OGÓREK R. Characterisation of the Relationships between Wheat Cultivars, Fusarium Head Blight and Mucofl ora Grains. Polish Journal of Environmental Studies. 25 (3), 1373, 2016.

16. ANUSZ K., SZCZAWIŃSKI J. Threats of bioterrorism and agroterrorism to food industry. Proceedings of the International Conference organized by the Military Institute of Hygiene and Epidemiology in Puławy "Protection against bioterrorism", Puławy, Poland, June 24-25. 18, 2003.

17. DANISZEWSKI P. Bioterroryzm - zagrożeniem dla bezpieczeństwa regionalnego i światowego. (Bioterrorism -threat to regional security and global). International Letters of Social and Humanistic Sciences. 1, 28, 2013.

18. MICHALIUK B. Broń biologiczna i bioterroryzm. (Biological weapon and bioterrorism.) Zeszyty Naukowe AON, 1 (102), Warszawa. 17, 2016.

19. BAUER J., BEKTAS T., CRAINIC T.G. Minimizing greenhouse gas emissions in intermodal freight transport: an application to rail service design. J. Oper. Res. Soc. 61, 530, 2010.

20. BAূK-GAJDA D., BĄK J. Psychologia transportu i bezpieczeństwa ruchu drogowego. (Psychology of Transport and Road Traffic Safety.) Wydawnictwo Difin S.A., Warszawa. 76, 2010.

21. DEMIR E., BEKTAS T., LAPORTE G. A comparative analysis of several vehicle emission models for road freight transportation. Transport. Res. Part D. 16, 347, 2011.

22. GARCÍA-ÁLVAREZ A., PÉREZ-MARTÍNEZ P.J., GONZÁLEZ-FRANCO I. Energy consumption and carbon dioxide emissions in rail and road freight transport in Spain: a case study of car carriers and bulk petrochemicals. J. Intell. Transport. Syst., Technol., Plan., Oper. 17 (3), 233, 2013.

23. KRAUTZBERGER L., WETZEL H. Transport and $\mathrm{CO}_{2}$ : productivity growth and carbon dioxide emissions in the European commercial transport industry. Environ. Resource Econ. 53 (3), 435, 2012.

24. ZAMBONI G., ANDRÉ M., ROVEDA A., CAPOBIANCO M. Experimental evaluation of Heavy Duty Vehicle speed patterns in urban and port areas and estimation of their fuel consumption and exhaust emissions. Transport. Res. Part D. 35, 1, 2015.

25. WASILEWSKI J., BURSKI Z., KRASOWSKI E. Kinetics modeling service verification of vehicle speed using the statistical significance in an urban food distribution. TEKA Komisji Motoryzacji i Energetyki Rolnictwa. 14 (3), 129, 2014. 
26. BLACK W.R. Sustainable transport and potential mobility. Eur. J. Trans. Infrastruct. Res. 2 (3-4), 179, 2002.

27. DREWES N., JASPERSEN H., PETERSEN T. Freight transport growth - a theoretical and methodological framework. Eur. J. Oper. Res. 144, 295, 2003.

28. BURSKI Z., WASILEWSKI J., MIJALSKA-SZEWCZAK I., SZCZEPANIK M. Analysis of energy consumption of food transit in an urban agglomeration in Poland. Transportation Research Part D. 31, 165, 2014.

29. BURSKI Z., MIJALSKA-SZEWCZAK I., WASILEWSKI J., SZCZEPANIK M. Evaluation of energy consumption of vehicles in EU Trans-European Transport Network. Transportation Research Part A. 92, 120, 2016.

30. CHEVASSUS-LOZZA E., LATOUCHE K., MAJKOVIĆ D., UNGURU M. The importance of EU-15 borders for CEECs agri-food exports: The role of tariffs and non-tariff measures in the pre-accession period. Food Policy. 33, 595, 2008.

31. HOP G.E., MOURITS M.C.M., SLAGER R., OUDE LANSINK A.G.J.M., SAATKAMP H.W. Prospects for cost reductions from relaxing additional cross-border measures related to livestock trade. Preventive Veterinary Medicine. 109, 278, 2013.

32. Ustawa z dnia 27 sierpnia 2003 roku o weterynaryjnej kontroli granicznej (The Act of 27 August 2003: On Veterinary Border Control). Dziennik Ustaw (Journal of Laws). 165, item 1590, 2003.

33. www.wetgiw.gov.pl

34. Council Regulation (EC) No 1/2005 of 22 December 2004 on the protection of animals during transport and related operations and amending Directives 64/432/EEC and 93/119/EC and Regulation (EC) No 1255/97. 2005.

35. Zintegrowany wieloletni plan kontroli dla Polski. Raporty roczne 2008-2014. (Integrated multiannual national control plan for Poland. Annual reports 2008-2014), Warsaw. 20092015.

36. GERAVANDI S., GOUDARZI G.R., VOSOUGHI NIRI M., MOHAMMADI M.J., SAEIDIMEHR S. Estimation of the cardiovascular and respiratory mortality rate resulted from exposure to sulfur dioxide pollutant in Ahvaz. Journal of Environmental Studies. 41, 341, 2015.

37. NEISI A., GOUDARZI G., AKBAR BABAEI A., VOSOUGHI M., HASHEMZADEH H., NAIMABADI A., MOHAMMADI M.J., HASHEMZADEH B. Study of heavy metal levels in indoor dust and their health risk assessment in children of Ahvaz city, Iran. Toxin Reviews. 35, 16, 2016.

38. YARI A.R., GOUDARZI G., DOBARADARAN S., YOUSEFI F., IDANI E., JAMSHIDI F., SHIRALI S., KHISHDOST M., MOHAMMADI M.J. Study of groundlevel ozone and its health risk assessment in residents in Ahvaz City, Iran during 2013. Toxin Reviews. 35, 201, 2016.

39. KHAEFI M., GERAVANDI S., HASSANI G., YARI A.R., SOLTANI F., DOBARADARAN S., MOOGAHI S., MOHAMMADI M.J., MAHBOUBI M., ALAVI N., FARHADI M., KHANIABADI Y.O. Association of Particulate Matter Impact on Prevalence of Chronic Obstructive Pulmonary Disease in Ahvaz, Southwest Iran during 2009-2013. Aerosol and Air Quality Research. 17, 230, 2017. 
